\title{
Period of Weed Interference in Bean With Nitrogen Fertilizer
}

\author{
Serena Capriogli Oliveira ${ }^{1}$, Lorena R. S. Peres ${ }^{1}$, Neriane Hijano ${ }^{1} \&$ Pedro Luis da C. A. Alves ${ }^{1}$ \\ ${ }^{1}$ Weed Sciences Laboratory, São Paulo State University, Jaboticabal, SP, Brazil \\ Correspondence: Lorena R. S. Peres, Weed Sciences Laboratory, University of Sao Paulo, Via de Acesso Prof. \\ Paulo Donato Castellane s/n, 14884-900, Jaboticabal, São Paulo, Brazil. Tel: 55-173-209-7100/7732. E-mail: \\ lorennaperess@hotmail.com
}

Received: December 17, 2018

Accepted: February 1, 2019

Online Published: April 15, 2019

doi:10.5539/jas.v11n5p381

URL: https://doi.org/10.5539/jas.v11n5p381

\begin{abstract}
The competition between weeds and bean plants, mainly by nutrients of the environment, is one of the main causes of low crop yield. Therefore, the objective of this study is to evaluate the effects of nitrogen fertilization on the extension of the period prior to interference (PPI) in common beans, cultivar TAA GOL. Sowing was performed in conventional system. The treatments were divided into two groups: cover nitrogen fertilization $\left(200 \mathrm{~kg} \mathrm{urea} \mathrm{ha}^{-1}\right)$ and no cover fertilization. Within each area, we established periods of cohabitation of the crop with weeds from the emergence up to seven times of its life cycle (0-10, 0-20, 0-30, 0-40, 0-50, 0-60, 0-70 days) and a control. The experiment design was randomized blocks with three replicates. Digitaria spp. presented a greater relative importance in both areas, followed by Eleusine indica. The period prior to weed interference (PPI) in the area with nitrogen fertilization occurred up to 46 days after emergence (DAE), and only up to 3 DAE for the area without cover fertilization. There was a $30 \%$ decrease in bean productivity by comparing the area with nitrogen fertilization $\left(2,004.79 \mathrm{~kg} \mathrm{ha}^{-1}\right)$ and the area without nitrogen fertilization $\left(1,412.43 \mathrm{~kg} \mathrm{ha}^{-1}\right)$. Therefore, nitrogen fertilization increased crop yield and favored it competitively in relation to weeds by increasing the weed PPI.
\end{abstract}

Keywords: Phaseolus vulgaris L., competition, Digitaria spp.

\section{Introduction}

Brazil is among the world's top three bean producers 3,389 million tons are expected in the 2018 harvest (IBGE, 2018). The mean yield is approximately $1,069 \mathrm{~kg} \mathrm{ha}^{-1}$, relatively low considering the possibility of obtaining an average of $3,483 \mathrm{~kg} \mathrm{ha}^{-1}$. Among the causes of such a low crop yield, weed interference stands out as it may affect bean growth, development and productivity (Patil et al., 2014). Bean yield losses caused by weeds may range from $25 \%$ to $77 \%$ depending on the crop and the environment (Osipitan et al., 2016).

Competition is the best-known form of direct interference of weeds in agricultural crops, the resources most often leading to competition are nutrients, light, water and space (Pitelli, 1987). There are three important periods of coexistence analyzed by interference studies, as Pitelli and Durigan (1984) have proposed: total interference prevention period (PTPI), pre-interference period (PPI) and critical prevention interference period (CPIP).

The duration of the coexistence period between plants and the season in which competition is established, as well as edaphoclimatic conditions, management techniques, the abundance and distribution of weeds, influence the response of plants to weed interference (Xiao-Yan et al., 2015). The extension of coexistence periods can be affected by several factors, among which there is mineral fertilization, especially nitrogen fertilization, which favors both crop and weed growth (Pitelli, 1987). Among nutrients, nitrogen is required in a greater quantity by common beans. Depending on the cultivar, it has a greater or less capacity of atmospheric nitrogen fixation by the action of $\mathrm{N}_{2}$-fixating bacteria existent in the nodules formed in the root system (Bordin et al., 2003). In addition to providing adequate plant nutrition and increasing bean productivity, nitrogen provides the crop with better conditions to compete with weeds. Coelho et al. (2001) reported that nitrogen application resulted in a $50 \%$ decrease in weeds, a higher number of pods per plant and a $64 \%$ increase in bean productivity.

Bressanin et al. (2013), for example, observed that Rubi beans could coexist with the weed community up to 38 days after emergence in an area with nitrogen fertilization. In an area without nitrogen fertilization, this culture could coexist with the weed community only up to 18 days after emergence. This period is called period prior to interference (PPI). 
Thus, considering that nitrogen fertilization has recently been adopted for bean cultivation and that weed interference may be affected by this crop management practice, this study aims to evaluate the effects of using nitrogen fertilization on the period prior to weed interference in the bean crop cultivar TAA GOL.

\section{Material and Methods}

The experiment was conducted in Jaboticabal, SP, Brazil $\left(21^{\circ} 15^{\prime} 22^{\prime \prime} \mathrm{S}, 48^{\circ} 18^{\prime} 58^{\prime \prime} \mathrm{W}\right.$ and altitude of $\left.595 \mathrm{~m}\right)$. The climate of the region is subtropical Cwc (Peel et al., 2007), with a dry winter and a rainy summer.

The soil is a eutrophic Red-Dark Latosol with a clay texture. The results of chemical and physical analyses were pH: 5.0; OM: $19 \mathrm{~g} \mathrm{dm}^{-3}$; P (res.): $20 \mathrm{mg} \mathrm{dm}^{-3}$; K, Ca, Mg, H+Al, BS, CEC and V (\%): 2.5, 23, 19, 10, 25, 31.5, 56.5 and 56, respectively; clay, silt, fine sand and coarse sand contents: $36,7,26$ and $31 \mathrm{~g} \mathrm{~kg}^{-1}$, respectively. The meteorological data used in this work were obtained through the Agrometeorology station of the Department of Exact Sciences of Unesp Jaboticabal SP (Figure 1).

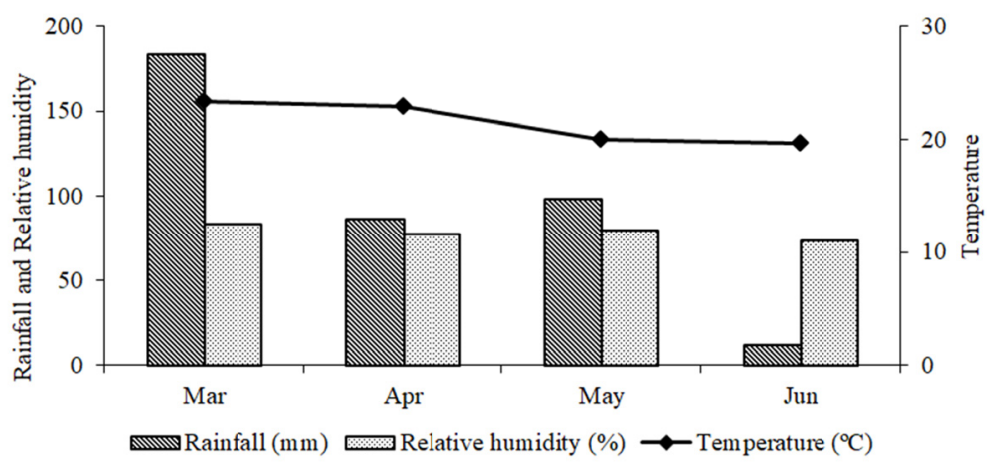

Figure 1. Climatic conditions during the experiment period with common beans cv. TAA GOL

Soil preparation was carried out using the conventional system, with plowing followed by two harrowings. The sowing was mechanized (fertilizer seeder Jumil EXACTA air 2640 PD) at a density of 15 seeds per meter, $0.50 \mathrm{~m}$ spacing between rows. The bean cultivar was TAA GOL, with a determined growth habit (type I), average dry yield potential of $3,000 \mathrm{~kg} \mathrm{ha}^{-1}$, resistant to common mosaic and Fusarium wilt.

The experiment conducted in a conventional area irrigated by spraying whenever necessary. The plots consisted of five lines of beans, four meters long each, resulting in an area of $10 \mathrm{~m}^{2}$. As the useful area used for evaluation were considered the three central lines, totaling in an area of $6 \mathrm{~m}^{2}$. There were 16 treatments separated into two different groups. The first group did not receive cover nitrogen fertilization and the second group received nitrogen fertilization as adequate to this crop $\left(200 \mathrm{~kg} \mathrm{ha}^{-1} \mathrm{~N}\right)$ when plants had were at the fourth vegetative node (V4). Urea was the source. In each group, eight treatments were set up corresponding to coexistence periods with weeds: from emergence and seven times of its life cycle: 0-10, 0-20, 0-30, 0-40, 0-50, 0-60 and 0-70 days (harvest), and one control. After each coexistence interval, the plots were kept without weeds until harvest by periodical manual weeding.

The experiment design was randomized blocks with three replications. At the end of each coexistence period and to collect data for the phytosociological study, two frames of $0.25 \mathrm{~m}^{2}$ were thrown at random over the experimental plots and the weeds inside them were identified, counted, removed and dried in a greenhouse with forced air circulation at $70{ }^{\circ} \mathrm{C}$ for 96 hours to determine dry matter. According to Mueller-Dombois and Ellemberg (1974), the relative importance (RI) was calculated using density and dry matter data.

The harvest was carried out March, 201582 days after sowing. The existing plants in three meters of the two central lines of the plot were collected, totaling six meters per plot. After harvested, the plants were left outdoors to dry. When the grain moisture reached approximately $13 \%$, a mechanical threshing of pods was performed. Moisture standardization of the grains collected in the dry chamber was carried out. Later, grains were weighed to estimate total crop yield $\left(\mathrm{kg} \mathrm{ha}^{-1}\right)$ and mass of 100 grains.

For the determination of the period prior to interference (PPI), yield data were submitted to regression analysis using the exponential model in the software MicroCalOrigin v. 8.0. (OriginalLab Corporation, USA), considering a $5 \%$ loss of productivity of common beans as acceptable. 


\section{Results and Discussion}

The weed community comprised 26 weed species from 15 different families; $69.23 \%$ were dicotyledonous (eudicotyledonous) and $30.77 \%$ were monocotyledonous. Among dicotyledonous, there were four species of Asteraceae and two species of Amaranthaceae, Brassicaceae and Fabaceae each. The families Boraginaceae, Convolvulaceae, Lamiaceae, Malvaceae, Phyllanthaceae, Portulacaceae, Rubiaceae and Solanaceae, with one species each, were also present. Among monocotyledons, there were six species of Poaceae. Commelinaceae and Cyperaceae families were also part of the weed community.

In the area without cover nitrogen fertilization, a high density of weeds was observed at the beginning of crop

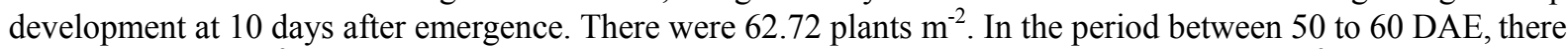
were 37.9 plants $\mathrm{m}^{-2}$. The lowest density for this area occurred near harvesting: 20.68 plants $\mathrm{m}^{-2}$ (Figure 2).

The initial predominance and the subsequent suppression of weeds corroborate other studies, such as Corrêa et al. (2015). By determining weed interference periods in 'Caupi' beans, the authors reported higher weed densities between 30 and $40 \mathrm{DAE}$ with an average of 1,068 plants $\mathrm{m}^{-2}$, occurring a rapid decrease until the harvest of the crop. Osipitan et al. (2016) observed a greater density and competition of weeds in the period between 14 and 40 DAE.

In another study, also related to the critical control period of weeds, on "French" bean (Phaseolus vulgaris L.). By Jahanbakhshi and Saeedipour (2015) concluded that dicotyledonous and monocotyledonous weeds reached greater densities at 48 DAE presenting 45 and 49 plants $\mathrm{m}^{-2}$ respectively, decreasing near the harvest to 26 and 28 plants $\mathrm{m}^{-2}$ respectively. The authors also found that monocotyledonous plants cause grater damage to the crop.

For the experimental area with cover fertilization, the highest weed densities occurred from 30 to 50 DAE. The maximum density occurred at $40 \mathrm{DAE}$, with 60.76 plants $\mathrm{m}^{-2}$, and the minimum, also near harvesting, with 14.36 plants $\mathrm{m}^{-2}$ (Figure 2). Bressanin et al. (2013) observed higher weed densities between 0 to 30 DAE for areas with and without cover fertilization, respectively. The maximum density occurred in the area without fertilization with 275 plants $\mathrm{m}^{-2}$ at $19 \mathrm{DAE}$, and 104 plants $\mathrm{m}^{-2}$ constantly up to $30 \mathrm{DAE}$ in the area with cover fertilization. Moreover, in this work it is possible to observe that lower densities were found in the area treated with nitrogen fertilizer, with 47 plants $\mathrm{m}^{-2}$ against 66 plants $\mathrm{m}^{-2}$ near the harvesting in the area that wasn't fertilized.

Nitrogen fertilization management, other than improving growth and productivity also increases the cultivar's competitivity, suppressing weeds growth.

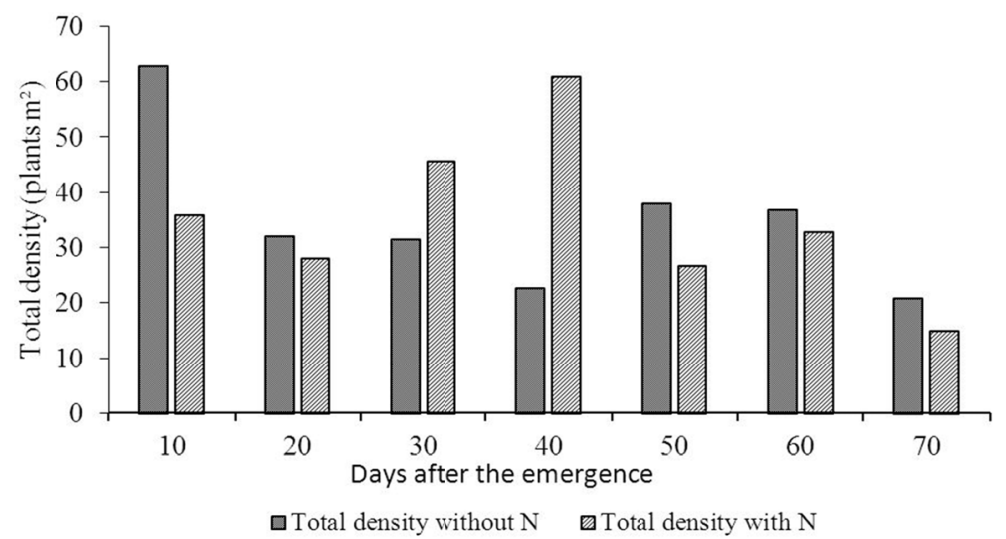

Figure 2. Total weed density (plant $\mathrm{m}^{-2}$ ) that composed the weed community in response to the period of coexistence with the bean crop

The species observed with the highest frequency and density were Digitaria spp., Eleusine indica, Acanthospermun hispidum and Raphanus raphanistrum only in the area with cover fertilization, and Lepidium virginicum in the area without nitrogen fertilization.

Weed dry matter increased from 0 to 70 DAE. The maximum DM was at $70 \mathrm{DAE}$, with $167.16 \mathrm{~g} \mathrm{~m}^{-2}$ in the area with nitrogen fertilization and $74.48 \mathrm{~g} \mathrm{~m}^{-2}$ in the area without fertilization. However, the highest weed densities occurred between 30 and $50 \mathrm{DAE}$ in the area without fertilization and between 40 and $70 \mathrm{DAE}$ in the area with fertilization (Figure 3). 
At high densities, weeds were characterized by different sizes and development stages due to different emergence flows that occurred in the experimental area.

According to Radosevich and Holt (1984), as weeds increase in density and development, especially weeds that germinated and emerged at the beginning of a crop cycle, such as that of beans, interspecific and intraspecific competition is intensified. Thus, larger and more developed weeds become dominant and consequently smaller ones are suppressed or die. This behavior explains the decrease in weed density with the increase in dry matter during the final bean development periods.

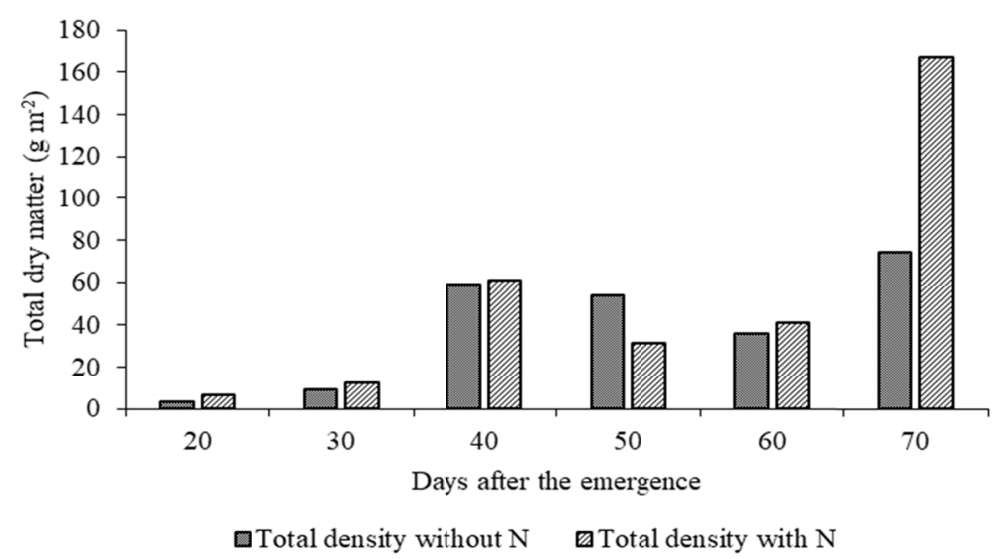

Figure 3. Weed total dry matter $\left(\mathrm{g} \mathrm{m}^{-2}\right)$ that composed the weed community in response to the period of coexistence with the bean crop

By analyzing relative frequency, density and dominance, some weed populations presented a greater relative importance (RI) than other populations. Digitaria spp. and E. indica stood out in both areas. The population with the highest sum of relative importance index (RI) during the experimental period was Digitaria spp, totaling $136.36 \%$ in the area without fertilization and $172.6 \%$ in the area with nitrogen fertilization. In the area without fertilization, the lowest index was observed at $30 \mathrm{DAE}$ (15.7\%) and the highest at $50 \mathrm{DAE}$ (25.04\%). Except for 20 DAE and 30 DAE, the RI of this species was always above $22 \%$ (Figures 4-5).

In the area with nitrogen fertilization, the lowest RI was observed at 30 DAE (22.88\%) and the highest at 50 DAE (34.44\%). With the exception of $30 \mathrm{DAE}$ and $70 \mathrm{DAE}$, the RI of this species in this condition was always above $29 \%$ (Figure 5). The population with the second highest RI sum was E. indica, totaling $128.5 \%$ in the area without fertilization and $83.97 \%$ in the area with fertilization. In the area without fertilization, the lowest index for $E$. indica was at $60 \mathrm{DAE}(11.03 \%)$ and the highest was at $40 \mathrm{DAE}(38.15 \%)$. Except for 60 and $70 \mathrm{DAE}$, the RI of this species was always above $18 \%$ (Figure 3a). In the area with nitrogen fertilization, the lowest RI was observed at 60 DAE $(8.61 \%)$ and the highest at 40 DAE $(21.16 \%)$ (Figures 4-5).

Corrêa et al. (2015) found that the grain yield of the Cowpea Vigna unguiculata (L.) decreased by about $36 \%$ due to interference of weeds, amongst them, E. indica and Digitaria spp. This specie develops preferentially in fertile soils, is resistant to drought conditions and has allelopathic effects on cultivated plants. The plant $E$. indica, although it has a well-developed root system (Lorenzi, 2014), and low fertility or compacted soils has advantage over other species. Each plant is capable of producing more than 120 thousand seeds (Takano et al., 2016).

The high competitivity of the Digitaria spp. and E. indica weeds may be related to the cycle C4 of carbon assimilation, which lowers the species germination time, increases growth speed, and also increased infestation density; by means of several anatomic and physiologic characteristics that yield them resistant to ambient stress and more productive (Anderson \& Nielsen, 1996; Aguyoh \& Masiunas, 2003).

A. hispidum presented an intermediate RI for both areas: 60.6 and $61.5 \%$, respectively. $R$. raphanistrum obtained a similar RI, except in the area without fertilization, not exceeding 35\% (Figures 4-5). Parreira et al. (2011) reported the contrary. By evaluating the period prior to interference of common beans with different spacing and densities, the authors observed that the species with the highest RI in the area were A. hispidum, R. raphanistrum and Cenchrus echinatus, very common in areas of common beans. 


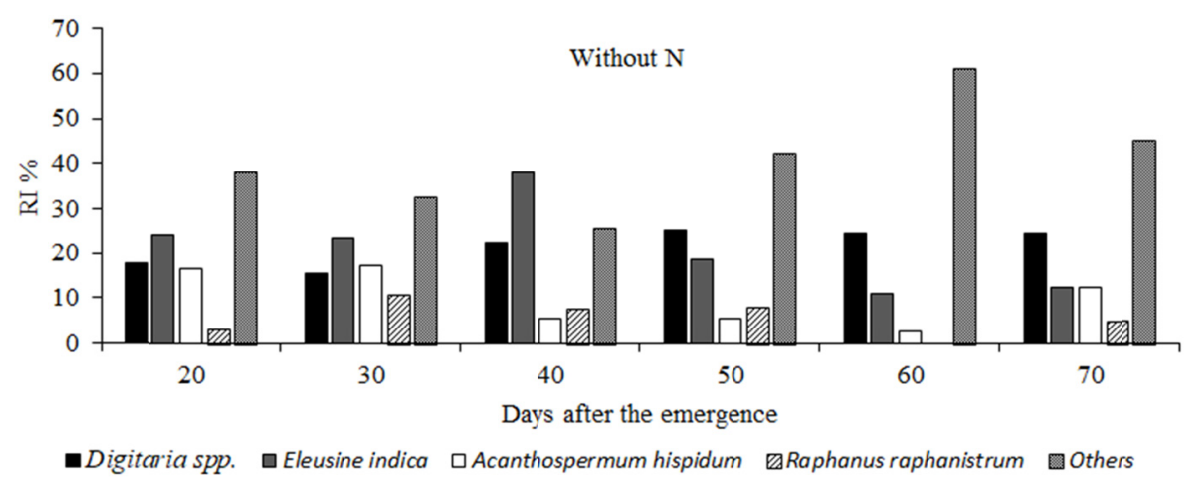

Figure 4. Relative importance (\%) of the main weeds and other plants that composed the weed community at the end of coexistence period without cover fertilization

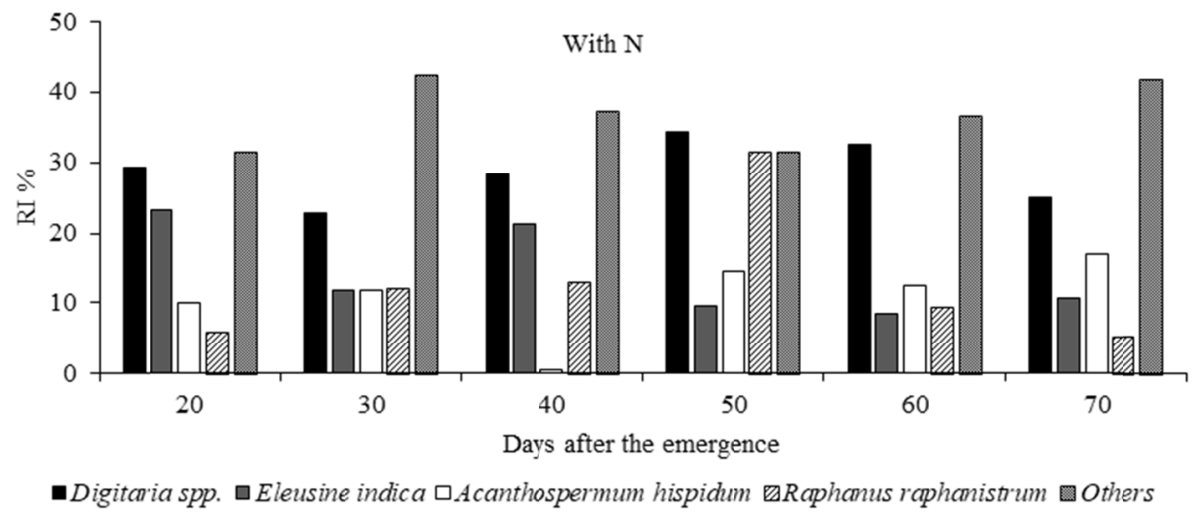

Figure 5. Relative importance (\%) of the main weeds and other plants that composed the weed community at the end of coexistence period with cover fertilization

There was a $30 \%$ decrease in bean productivity by comparing the area with nitrogen fertilization $\left(2,004.79 \mathrm{~kg} \mathrm{ha}^{-1}\right)$ and the area without fertilization $\left(1,412.43 \mathrm{~kg} \mathrm{ha}^{-1}\right.$ ) (Figure 6). In relation to treatments, there was a 33\% decrease in bean productivity when comparing productivity obtained in total absence of weeds (control cycle) $(2,146.11 \mathrm{~kg}$ $\left.\mathrm{ha}^{-1}\right)$ with productivity obtained in the presence of weeds during the whole cycle $\left(1,434.45 \mathrm{~kg} \mathrm{ha}^{-1}\right)$ regardless of $^{-1}$ the coexistence period. The decrease in bean yield was due to weed interference and was also reported by other studies (Adigun et al., 2014; Osipitan et al., 2016).

The mass of 100 grains was $27.47 \mathrm{~g}$ for the area with fertilization and $25.70 \mathrm{~g}$ for the area without fertilization. It is a significant difference. Farinelli et al. (2006) verified that the mass of 100 of 'Pérola' beans was influenced by soil management and different doses of cover nitrogen fertilization. Chekanai et al. (2018) corroborated these results: the fertilization of common beans at $40 \mathrm{~kg} \mathrm{ha}^{-1}$ significantly increased the number of pods per plant, the number of seeds per pod and the grain yield. There was also a significant decrease in pod mass when comparing the area with fertilization $\left(1,873.7 \mathrm{~kg} \mathrm{ha}^{-1}\right)$ and without fertilization $\left(1,331.2 \mathrm{~kg} \mathrm{ha}^{-1}\right)$.

The period prior to interference (PPI), tolerating up to 5\% decrease in productivity, extended until 3 DAE in the area without cover fertilization. It corresponds to the phenological stage V2, according to Fernández (1986. In the area with nitrogen fertilization, the crop could coexist with the weed community up to 46 days after emergence (DAE). It corresponds to the phenological stage R5, according to Fernández (1986). The increase in PPI probably occurred because the crop was favored by cover nitrogen fertilization, making it more competitive (Figure 6).

Bressanin et al. (2013), however, conducted a similar study on the cultivar Rubi. By evaluating the influence of nitrogen fertilization in the period prior to weed interference, the authors reported that in the area without cover fertilization, the culture could coexist with the weed community up to 18 DAE. In the area with cover fertilization, this period extended up to $38 \mathrm{DAE}$. Scholten et al. (2011) analyzed the period prior to weed interference (PPI) of a 'Rubi' bean crop with different plant spacing and densities. The authors verified that, when the common bean grew with weeds during the whole cycle, the grain yield reduced to $50 \%$ in a treatment with a spacing of $0.45 \mathrm{~m}$ and 
sowing density of 15 plants $\mathrm{m}^{-1}$. Barroso et al. (2012) obtained a $19 \%$ decrease in yield of common beans grown in the spring.

However, many factors may interfere with the period prior to weed interference, such as environmental conditions, weed infestation, weed composition, management practices, soil moisture, soil fertility and plant density (Adigun et al., 2014; Osipitan et al., 2016).

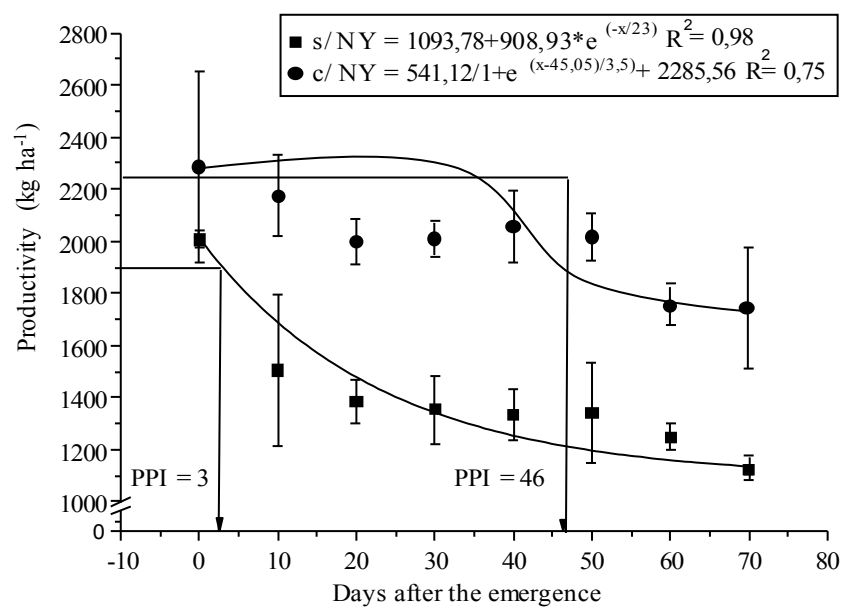

Figure 6. Productivity of the common bean TAA GOL in areas without $(\mathrm{s} / \mathrm{N})$ and with nitrogen fertilization $(\mathrm{c} / \mathrm{N})$ in function of control periods and coexistence with weeds considering a loss of $5 \%$, and determination of period prior to interference (PPI)

\section{Conclusion}

The weeds with a great relative importance to the common bean crop 'TAA GOL' were Digitaria spp. and $E$. indica.

Cover nitrogen fertilization increased bean productivity even in the presence of weeds. It benefited the crop and, consequently, increased the period prior to weed interference (PPI).

Common bean 'TAA GOL' bean can coexist with the weed community for up to 3 DAE (PPI) without decreasing its productivity in areas without nitrogen fertilization and up to 46 DAE in areas with nitrogen fertilization.

\section{References}

Adigun, J., Osipitan, A. O., Lagoke, S. T., Adeyemi, R. O., \& Afolami, S. O. (2014). Growth and yield performance of cowpea (Vigna unguiculata (L.) Walp) as influenced by row-spacing and period of weed interference in South-West Nigeria. Journal of Agricultural Science, 6(4), 188. https://doi.org/10.5539/ jas.v6n4p18

Aguyoh, J. N., \& Masiunas, J. B. (2003). Interference of redroot pigweed (Amaranthus retroflexus) with snap beans. Weed Science, 51, 202-207. https://doi.org/10.1614/0043-1745 (2003)051 [0202:IORPAR] 2.0.CO;2

Anderson, R. L., \& Nielsen, D. C. (1996). Emergence pattern of five weeds in the Central Greal Plains. Weed Technology, 10, 744-749. https://doi.org/10.1017/ S0890037X00040756

Barroso, A. A. M., Alves, P. L. C. A., Yamauti, M. S., \& Nepomuceno, M. P. (2012). Weed communities and their interference in no-tillage bean sown in the spring season. Planta Daninha, 30(2), 279-286. https://doi.org/10. 1590/S0100-83582012000200006

Bordin, L., Farinelli, R., Penariol, F. G., \& Filho, D. F. (2003). Double crop-commom bean with upland rice, submitted to rates of nitrogen fertilization after green cover under no-tillage system. Bragantia, 62(3), 417-428. https://doi.org/10.1590/S0006-87052003000300008

Bressanin, F. N., Nepomuceno, M., Martins, J. V. F., Carvalho, L. B., \& Alves, P. L. C. A. (2013). Period of weed interference in bean with nitrogen fertilizer. Revista Ceres, 60(1), 43-52. https://doi.org/10.1590/S0034737X2013000100007

Coelho, F. C., Freitas, S. P., Monerat, P. H., \& Dornelles, M. S. (2001). Effects of nitrogen fertization, molybdenum as foliar spray and weed management of common beans. Revista Ceres, 48, 455-468. 
Corrêa, M. J. P., Alves, G. L., Rocha, L. F., \& Silva, M. R. M. (2015). Periods of weed interference in cowpea. Revista de Ciências Agroambientais, 13(2), 50-56.

Chekanai, V., Chikowo, R., \& Vanlauwe, B. (2018). Response of common bean (Phaseolus vulgaris L.) to nitrogen, phosphorus and rhizobia inoculation across variable soils in Zimbabwe. Agriculture, Ecosystems \& Environment, 266, 167-173. https://doi. org/10.1016/j.agee.2018.08.010

Farinelli, R., Lemos, L. B., Penariol, F. G., Egéa, M. M., \& Gasparoto, M. G. (2006). Nitrogen topdressing in common bean in no tillage and conventional tillage system. Pesquisa Agropecuária Brasileira, 41(2), 307-312. https://doi.org/10.1590/S0100-204X2006000200016

Fernández, F., Gepts, P., \& López, M. (1986). Etapas de desarrollo de la planta de frijol común (Phaseolus vulgaris $L$.). Cali, Colombia: CIAT.

IBGE (Instituto Brasileiro de Geografia e Estatística). (2018). $4^{\circ}$ Levantamento Sistemático da Produção Agrícola (LSPA) de 2018. Retrieved November 1, 2018, from https://www.ibge.gov.br

Jahanbakhshi, M., \& Saeedipour, S. (2015). Determination of critical period of weeds control in French bean (Phaseolus vulgaris L.) in Iran. International Journal of Biosciences, 6(2), 411-417. https://doi.org/10.12692/ ijb/6.2.411-417

Lorenzi, H. (2014). Weed identification and control manual. São Paulo, SP: Instituto Plantarum.

Mueller-Domboi, D., \& Ellemberg, H. (1974). Aims and methods of vegetation ecology. New York, NY: Willey \& Sons.

Osipitan, O. A., Adigun, J. A., \& Kolawole, R. O. (2016). Row spacing determines critical period of weed control in crop: Cowpea (Vigna unguiculata) as a case study. Azarian Journal of Agriculture, 3(5), 90-96.

Parreira M. C., Alves P. L. C. A., \& Peñaherrera-Colina L. A. (2011). Weeds influence in common bean as a function of spacing and plant density. Planta Daninha, 29(4), 761-769. https://doi.org/10.1590/S0100-8358 2011000400006

Patil, B. C., Padanad, L. A., Yashvantkumar, K. H., Soumya, S., \& Ravi, L. (2014). Efficacy and economics of integrated weed management in vegetable cowpea [Vigna unguiculata (L.) Walp]. Agriculture Update, 9(1), 124-127.

Peel, M. C., Finlayson, B. L., \& Mcmahon, T. A. (2007). Updated world map of the Köppen Geiger climate classification. Hydrobiology and Earth System Sciences, 11, 1633-1644. https://doi.org/10.5194/hess-111633-2007

Pitelli, R. A. (1987). Competição e controle das plantas daninhas em áreas agrícolas. Série Técnica IPEF, 4(12), $1-15$.

Pitelli, R. A., \& Durigan, J. C. (1984). Terminologia para períodos de controle e de convivência das plantas daninhas em culturas anuais e bianuais. Proceedings of the 1984 Congresso brasileiro de herbicidas e plantas daninhas (pp. 37-37). Brasil, Belo Horizonte: SBHED.

Radosevich, S. R., \& Holt, J. S. (1984). Weed ecology: Implications for vegetation management. New York, NY: John Wiley \& Sons.

Scholten, R., Parreira, M. C., \& Alves, P. L. C. A. (2011). Effect of spacing and seeding density in a period prior to weed interference of Phaseolus vulgaris 'Rubi'. Acta Scientiarum Agronomy, 33(2), 313-320.

Takano, H. K., Oliveira Júnior, R. S., Constantin, J., Braz, G. B. P., \& Padovese, J. C. (2016). Growth, development and seed production of goosegrass. Planta Daninha, 34(2), 249-257. https://doi.org/10.1590/ S0100-83582016340200006

Xiao-Yan, M. A., Han-Wen, W. U., Wei-Li, J., Ya-Jie, M. A., \& Yan, M. A. (2015). Goosegrass (Eleusine indica) density effects on cotton (Gossypium hirsutum). Journal of Integrative Agriculture, 14(9), 1778-1785. https://doi.org/10.1016/S2095-3119(15)61058-9

\section{Copyrights}

Copyright for this article is retained by the author(s), with first publication rights granted to the journal.

This is an open-access article distributed under the terms and conditions of the Creative Commons Attribution license (http://creativecommons.org/licenses/by/4.0/). 